\title{
Realizing Low Carbon Emission in the University Campus towards Energy Sustainability
}

\author{
Isiaka Adeyemi Abdul-Azeez', Chin Siong Ho² \\ ${ }^{1}$ Department of Urban \& Regional Planning, Modibbo Adama University of Technology, Yola, Nigeria \\ ${ }^{2}$ Faculty of the Built Environment, Universiti Teknologi Malaysia, Johor Bahru, Malaysia \\ Email: azeezabu@yahoo.com
}

Received 17 July 2014; accepted 12 May 2015; published 15 May 2015

Copyright (C) 2015 by authors and Scientific Research Publishing Inc.

This work is licensed under the Creative Commons Attribution International License (CC BY). http://creativecommons.org/licenses/by/4.0/

(c) (i) Open Access

\begin{abstract}
Energy consumption increases with intensity of human activities. People consume energy for movement and other activities and the more fossil-fuel based energy used, the more carbon dioxide $\left(\mathrm{CO}_{2}\right)$ emission. Since carbon dioxide is the major element of the greenhouse gases (GHG), this phenomenon has a serious implication for global warming and consequent climate change-a scenario that calls for sustainable development. This research considers the emission of $\mathrm{CO}_{2}$ from energy use within the campus of Universiti Teknologi Malaysia. Two major sources of energy consumption were identified, namely: electricity and transport. The emission for electricity was estimated based on electricity meter reading and the conversion rate in accordance with the standardized conversion factors for fuel mix of the purchased electric energy as given by PTM (Pusat Tenaga Malaysia), while the associated $\mathrm{CO}_{2}$ emission for transport was estimated based on the number of miles driven (VMT-Vehicle Miles Travel) within the campus, emissions produced per litre of gasoline, and fuel economy of vehicles plying the campus in line with the Code of Federal Regulations USEPA and consistent with the Inter-governmental Panel on Climate Change (IPCC) guidelines. It was observed that high $\mathrm{CO}_{2}$ emission resulted from electricity energy consumption, and the highest emission in the transport sector was produced by commuting vehicles while emission from service delivery for cooling, lighting and other equipment was similar to national average.
\end{abstract}

\section{Keywords}

Energy Sustainability, Carbon Dioxide Emissions, Sustainable Campus, Low Carbon Development 


\section{Introduction}

Emission of carbon dioxide continues to increase as energy consumptions grow, partly due to the age-long human habit of burning and the current technological practices that favor the use of fossil fuels as major sources of energy. The amount of carbon produced by the earth in the atmosphere has been of concern in recent time and the realization of low carbon emission will require an understanding of the source, type and quantity of energy use and the extent of emission from such sources. This involves the measurement and determination of extent of emission from the intensity of use. Generally, sustainability includes focusing on raising awareness to improve the overall image as well as bolstering the environmental prestige by encouraging the participation in the development of the strategies or policies for sustainable development, and also by providing incentives to influence and motivate people and institutions to be more active and focused. The assessment of energy sustainability through the emission of carbon dioxide is a key step for university campus sustainability.

Human activity and practices require energy for lighting, cooling and other domestic purposes as well as for movements and manufacturing and to sustain life. However, some sources of energy usually place stress on the environment and result in the emissions of carbon dioxide and other greenhouse gases (GHG). Most carbon emission is as a result of combustion from fossil fuel based energy use. Therefore, the more energy is consumed, the more stress is placed on the environment [1]. This is usually in the form of greenhouse gas emission which impacts negatively on the global environment. The continuous emission of $\mathrm{CO}_{2}$ into the atmosphere owing to global energy consumption has irreversible effects mostly catastrophic to Earth's global system and requiring attention in the form of low carbon development.

Low carbon development entails safeguarding the environment without slowing down socioeconomic development; this will require technological solutions, to keep pace with the rate of economic growth and to change current unsustainable patterns of consumption and production, in the society. It is essential that every country voluntarily takes part in dealing with the global environmental problem [2] by establishing leadership in both thought and action, to direct sustainability as well as show willingness to define and adopt quantitative sustainability goals specifically on energy to enable more responsibility in operations. This can also be helpful in providing the best options aimed at achieving the goals of energy sustainability in the university campus.

The problem of carbon emission is more pronounced specifically in universities with large population and large spatial size, whose design requires the use of automobile to travel from one place to another within the campus. Similarly, the teaching and learning service delivery, as well as the residential and administrative activities also involves high energy demand for lighting, cooling, and running appliances, while, the movement of vehicles within the campus consumes high amount of fossil fuel energy, whose consumption also results in the emission of carbon dioxide.

Similarly, the electricity consumption in operating machines and transportation fuels of the university campuses, results in high emission of carbon dioxide [3], having serious implication on environmental quality. Also the products of direct and indirect activities such as classrooms, laboratories, offices and the consumption of food and drinks generate negative environmental impacts [4]. The combine activities of the global university population constitute significant energy use; hence, universities offer great potential for sustainability globally [5]. Therefore, focusing on achieving reduction of carbon emission from energy use in university campuses by encouraging low carbon emission through the involvement of the universities and achieving energy sustainability within the campus by the reduction of carbon dioxide emission may benefit global energy sustainability and remedy the current problems of global warming.

The operational approaches to meet sustainability goals in the universities are diverse and the practices are very broad and include improved environmental performances that may not necessarily be equivalent to sustainability. Sustainability is linked with setting quantitative targets in areas such as energy use, water use, use of land, purchases of product and emissions to air, water and land and achieving sustainability in the university is a process of setting goals to determine the extent of the aspects of the university required to be sustained [6].

Therefore, sustainability in university campus infers adopting intellectually defendable target for meeting the transition to sustainability and then developing the approaches and time scale designed to reach the target [7]. Also, focusing on the assessment procedure of sustainability where quantitative or qualitative value measures of the paradigm are developed for particular situations will assist to meet legitimate sustainability targets especially in the universities and colleges.

Hence, each university must determine its goals for itself. This infers taking inventories and setting targets and finally planning the program of implementation of the actions necessary to achieve the targets and then re- 
peating the process all over. However, sustainability may not be easy to achieve in a quantitative manner unless it measures a criteria that is common among universities.

The ability to measure the extent, levels and impact of energy consumption in campuses will facilitate uniformity of practice of sustainability approach through common factors. This will limit global warming and reduce threat to global environment as well as enable the sharing of experience among the university campuses. However, it is necessary to determine the existing levels of emission in order to apply suitable strategies and mitigation measures to stop or reduce the use of the stuff that creates greenhouse gases.

Planning and implementation of policies to reduce carbon emission should be locally decided through the determination and measurement of emission sources because global warming impacts are better decided locally. Therefore, the inventory of carbon dioxide from transport and electricity focuses on energy consumption within UTM. Using the Malaysian University Campus Emission Tool (MUCET), the emissions are reported in percentages of metric tons of carbon dioxide $\left(\mathrm{tCO}_{2}\right)$ equivalent towards creating carbon reduction program to achieve more energy sustainable university campus. This will provide an understanding of the pattern and quantity of carbon dioxide emission within the campus, so that the university authority can plan emission reduction based on informed decisions.

\section{Importance of Energy Sustainability in University Campus}

Energy connects everything to everything else more universally and more quantifiably than any element [8]. It is evident today that carbon emission from fossil fuel based energy consumption is a common global sustainability issue, [9]-[11]. Energy is central to sustainability and there cannot be sustainable university development without sustainable energy development [12], therefore, energy sustainability in university sustainability drive is of great benefit to ameliorating global warming.

Colleges and universities have been at the forefront in addressing sustainability and global warming issues through innovative energy use, energy conservation practices and clean power technologies [13]. The American College and University Presidents' Climate Commitment (ACUPCC) is making effort to achieve sustainability among universities, through an initiative challenging institutions to quantify, reduce and ultimately eliminate their greenhouse gas emissions.

Similarly, other universities are grouping together to form partnerships to pursue the goals of sustainability. For instance the New Jersey (USA) Higher Education Partnership for Sustainability-(NJHEPS) in 2008, is also committed to reducing the greenhouse gas emissions and promoting positive changes in the environment of member universities.

In view of the benefits and importance of energy sustainability to human development and economic growth, the trends in university campus sustainability show the absence of consensus and lack universal direction regarding the approach and the development of sustainability in the sector.

It is evident that sustainability in the university campus presents a confusing scenario in terms of direction and universality. This is because the concept of sustainability presents diverging interpretations [14]. Researches in campus sustainability show concern for environmental issues along sustainable transportation in the university communities [15]-[17], as well as sustainability in waste management programs [18], while innovations in the green design movement including GIS-based evaluation of greenery [19], greening campus restaurant [20] and greenway corridor [21], green transport, green buildings, and green energy among others appear to be the trend. The assessment of the carbon dioxide emissions associated with on-campus electrical, natural gas and oil consumption is more common in the university in recent times [22].

In view of the benefits and importance of energy sustainability to human development, the trends in university campus sustainability show the absence of consensus and lack universal direction regarding the approach and the development of sustainability in the sector. It is evident that sustainability in the university campus presents a confusing scenario in terms of direction and universality.

The knowledge and quantification of energy indicators is important in the analysis and planning towards achieving sustainable energy development [23], as this will enable systematic monitoring of progress made towards the implementation of energy-related targets so as to reduce emission of carbon from energy source and attain effective management of the energy resources in the university campus. Finally, policies on achieving low carbon emission in university campus through implementation of climate action plan [24] are more common today. 
As a way to establish the quantities of carbon emission and set targets to mitigate the condition, attempts are made to develop the indices with which campus sustainability could be measured; example is the assessment of carbon dioxide emissions associated with on-campus electrical, natural gas and oil consumption [22]. More universities are developing carbon emission inventories [25]-[29].

The rationale for the investigation of the sources and nature of emission from energy use in UTM is in line with the energy consumption pattern as shown in Figure 1, where primary energy is utilized in the form of final energy for various activities, in buildings and for movements. There is evidence of high carbon emission related to energy use in universities. It is necessary therefore to create the awareness among Malaysian universities on the need for carbon reduction strategies to mitigate global warming potentials of the university. The research therefore examine sustainability policies and energy consumption of UTM and the types and sources of energy used on campus to support university core activities such as Teaching and Learning, Administration and support services, ICT, Hostels and movements within the campus of UTM as well as the carbon emission from such energy consumption.

\section{Sustainability Policies and Energy Consumption of Universiti Teknologi Malaysia (UTM)}

The existing campus sustainability practice in Universiti Teknologi Malaysia (UTM) include policies defined across three major aspects and policy areas, namely, the socio-cultural policy, economic policy and eco-system policy of the university. The socio cultural dimensions consists of two main objectives which is to develop open society with openness and reduce barrier, as well as to develop civil society, through respect high integrity and ethical values so as to promote community spirit that is responsive to local and global context through harmonious and conducive environment.

The economic policy of UTM's campus sustainability aim to achieve cost effectiveness by adopting green building and infrastructure design, promote economic viability, optimization of university assets and to achieve efficiency in operational management of resources and facilities as well as to ensure the smooth implementation of the policies. The eco-system Policy of the UTM focuses on the implementation of low carbon campus initiatives which aim to enhance campus lifestyle through the reduction of energy and water consumption and also to reduce Pollution.

UTM is a pioneer university of technology located within the Iskandar region south of Malaysia. It has a total of 12 faculties and occupies a total area of about 1157 hectares of built up land as well as green area. The gross

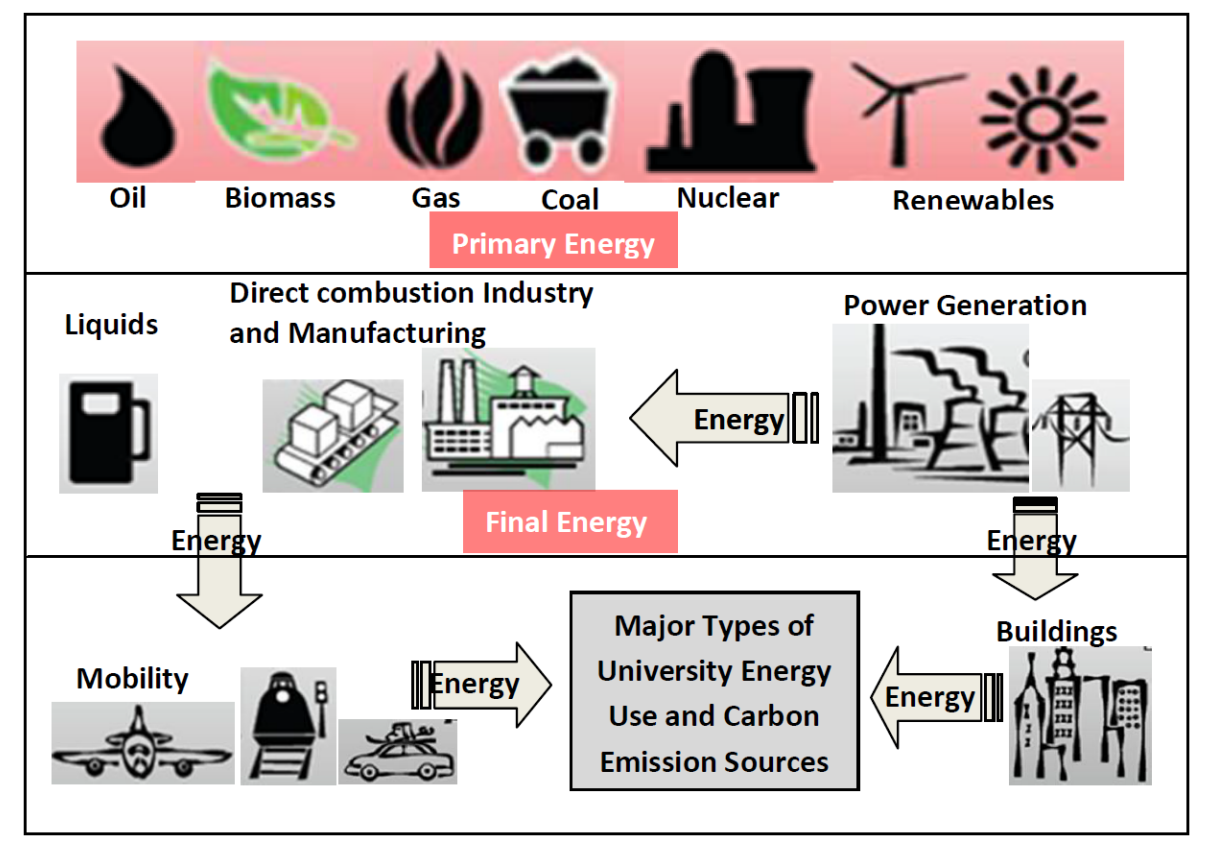

Figure 1. Energy consumption pattern (modified after David Hone, Shell International Ltd). 
built up area of UTM is about 813352.21 meter square, consisting of the Zones of Academic Faculty (30\%), students Hostels (56\%), Administrative and support services (9\%) and ICT Facilities area (5\%).

The university consists mostly of high rise buildings and structures, fitted with elevators that run for 24 hours, thereby consuming enormous quantity of electricity to run and operate various appliances for its specialized and educational service delivery, specifically teaching and learning activity and for the lighting and cooling, running of laboratory and office equipment for administrative as well as ICT purposes among others. This generates substantial amount of carbon emission from electricity use as well as from the combustion of fuel for internal vehicular movements of the shuttle buses, the university vehicular fleet and the commuting staff and students' vehicles. Figure 2 is a flow chart of energy pattern of the university, and a representation of the energy consumption pattern in most university campuses, upon which the study is focused.

The study of energy practices in Universiti Teknologi Malaysia is a current planning issue that identifies about $55,317,730 \mathrm{KwHr}$ as total annual electricity consumption, responsible for $70 \%$ of the total carbon emission in the campus. Therefore assessing the impact of university operations [10] on the climate and the initiatives of setting targets to reduce emission of $\mathrm{CO}_{2}$ in the university is a measure of campus sustainability [6] and a step towards reducing contribution of the university campus to global warming - an initiatives directed towards global sustainability.

\section{Design Methodology and Approach}

Data on electric energy consumption for domestic purpose were collected to identify the sectors with greater emission within the campus. The annual greenhouse gas emissions associated with vehicles were calculated based the number of miles driven (VMT) within the campus, fuel economy of vehicles, the carbon dioxide $\left(\mathrm{CO}_{2}\right)$ emissions produced per litre of gasoline, in line with the Code of Federal Regulations USEPA and consistent with the Inter-governmental Panel on Climate Change (IPCC) guidelines. The associated carbon dioxide emission of the total annual consumption of on-campus electrical energy use and the total amount of fuel consumption within the campus based on types of vehicles plying the campus was estimated and calculated using the Malaysian University Campus Emission Tool (MUCET).

The study of carbon emission is specialized and relates to activities that involve combustion of fossil fuel either in the form of liquid energy or generated electricity. For the purpose of accounting for carbon dioxide emission in UTM, the Malaysian University Carbon Emission Tool (MUCET) was employed to determine carbon emission from the university operations. The tool offer opportunity for the determination of the extent of emission and sectors of high emission, which could assist decision making towards reducing carbon emissions and creating energy sustainable campus.

MUCET calculated and provided information on the carbon emission from specific energy use sub systems of the university campus based on the conversion rate in accordance with the Pusat Tenaga Malaysia (PTM), standardized conversion factors for fuel mix for the purchased electricity, while the US Environmental Protection Agency (EPA) accepted method of calculating estimates for the annual GHG emissions associated with vehicle emissions in line with the IPCC standard was used to determine the emission from vehicles transport use within the campus. The tool was tailored towards university campus energy consumption patterns and relied on the structure of the university's service delivery pattern according to the structure of the university's energy flow (Figure 2). MUCET is also directed towards the determination of unit and total $\mathrm{CO}_{2}$ emissions of the campus aggregate input of energy use.

Since the rationale is to determine the extent and intensity of carbon emission, this study concentrated on two main sources of fossil fuel based energy identified within the campus, which is electricity and transport energy use. The data mainly involved:

1) Emissions from electricity based on combustion of fossil fuels for electricity and the fuel mix of external electricity generation (purchased electricity) of university campus;

2) Emissions from energy use in transportation (i.e. fuel combustion from vehicular movements of goods and services within the campus).

The study considers a total of five categories of energy service demand sectors namely; energy use for activities of the teaching and learning services, the residential accommodation, administrative and support services, the Information and communication technology and the transport sectors. The carbon emissions were assessed based on energy consumption pattern of the university, and the electricity and transport consumption for the university were categorized as follows: 


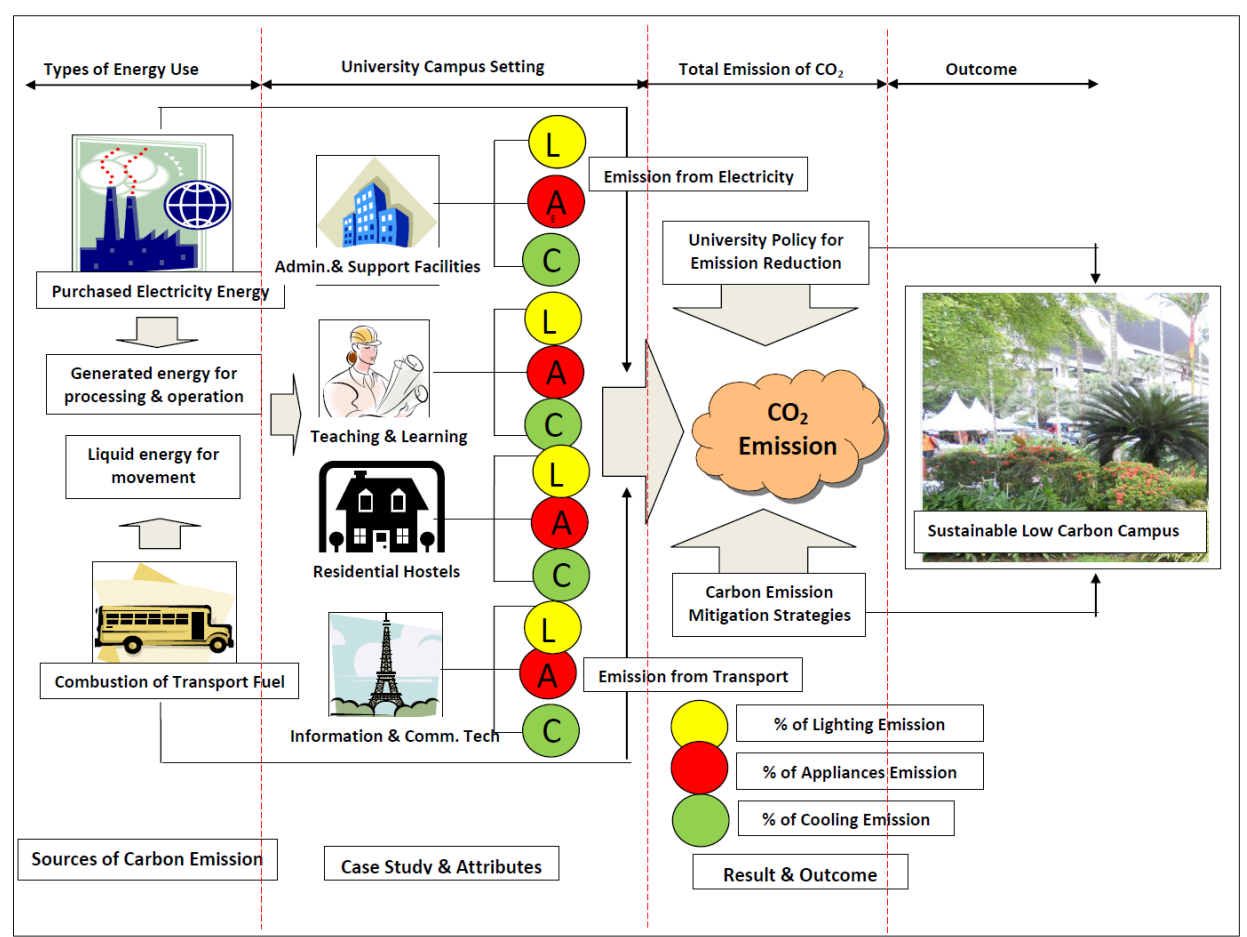

Figure 2. Flow chart of energy consumption and carbon emission of UTM, Malaysia.

Consumption for all the faculties of the university (i.e. teaching and learning sector):

1) Consumption for students hostels (residential accommodation);

2) Consumption for central administration and support services; and

3) Consumption for Information Communication Technology (ICT).

While the data on transport was classified as the $\mathrm{CO}_{2}$ emission from:

1) Fuel consumption of commuting staff and students vehicles;

2) Fuel consumption by on-campus shuttle buses;

3) Fuel consumption for university vehicle fleet.

For the purpose of this research, six (6) indicators responsible for carbon emission in the university were identified from the literature [30] [31]. Based on these indicators, the method used in this study affirms emissions estimates and allows policy prescriptions to reduce $\mathrm{CO}_{2}$ emissions in the university campus for the future. The indicators are given below as energy use for:

1) Lighting, cooling/space comfort and appliances;

2) Various service demands;

3) ICT and other operations;

4) University shuttle bus;

5) University vehicle fleet;

6) Internal circulation or commuting staff and students vehicles.

Based on these indicators, total emission for energy use [12] is computed as:

$$
E_{\text {total }}=E_{\text {electric }}+E_{\text {transport }}
$$

where,

$$
\begin{aligned}
& \text { 1) Electric energy, } E_{\text {electric }}=E_{T L}+E_{A S S}+E_{\text {HOSTEL }}+E_{\text {ICT }} \\
& \text { 2) Transport energy, } E_{\text {transport }}=E_{S B}+E_{\text {FLEET }}+E_{\text {COMMUtinG }}
\end{aligned}
$$

$\mathrm{E}_{\mathrm{TL}}=$ Energy for lighting, cooling/space comfort and appliances for Teaching and Learning Sector;

$\mathrm{E}_{\mathrm{AsS}}=$ Energy for Administration and Support Service;

$\mathrm{E}_{\text {HOSTEL }}=$ Energy for Hostel Accommodation; 
$\mathrm{E}_{\mathrm{ICT}}=$ Energy for Information \& Communication Technology;

$\mathrm{E}_{\mathrm{SB}}=$ Transport Energy use for Shuttle Bus;

$E_{\text {FLEET }}=$ Transport Energy use for University Vehicle Fleet;

$\mathrm{E}_{\text {COMMUTING }}=$ Transport Energy use for Commuting Staff and Students.

Therefore, the study relies on secondary data based electricity meter readings from Assets and Facilities department of UTM and also on data for fuel consumption of the university shuttle buses and the university vehicle fleet that were obtained from the transport section of the university as well as the fuel consumption for commuting staff and students vehicles, estimated based on average round trip derived from personal interview of staff, students and faculty members.

The data on electricity consumption in UTM was based on $100 \%$ survey of total electricity consumption for the year 2011. This was obtained from the recordings of the meter installations at the respective buildings. Twelve (12) academic faculties of UTM were observed and the Annual Area Energy Use Index (AEUI) expressed as $\mathrm{kW} \cdot \mathrm{h} / \mathrm{m}^{2}$ [32] was presented as total for teaching and learning sector. Population size and energy efficiency are among important factors that affect carbon emission [33], based on the emission pattern for the university buildings, Table 1 presents the units of population and activity space to enable the measurement of energy intensity and efficiency of energy use and to demonstrate electricity consumption per gross area. While carbon emissions are reported in metric tons of carbon dioxide $\left(\mathrm{tCO}_{2}\right)$ equivalent from the conversion of kilowatt hour $\mathrm{kWh}$ of electricity and litres of fuel into $\mathrm{CO}_{2}$ equivalent using the EPA standards based on IPCC guidelines [34] and on fuel mix of electricity for Malaysia Peninsula [35].

Finally, the carbon dioxide of each alternative sector was estimated by entering observed values of fuel and electricity in the baseline of the prototype calculator (MUCET), creating a measure of carbon dioxide emission for each of the sectors which allows a comparison of emission from all the sectors in order to assist university authority in making informed decision. Therefore, savings from the impact of the strategies of campus goal in terms of target setting or alternative policies can be established as percentage reductions of $\mathrm{CO}_{2}$ in sectors or the percentage of reduction from total campus emission.

\section{Result and Findings}

The measurement of the carbon emission from energy related sources in the campus is a potential to model transition to a low-carbon future and to facilitate the practice of energy sustainability in a manner easier to understand by university administration so as to set target and guidelines to achieve energy sustainability.

In this regard, it is essential to understand the characteristics of the study area. The basic characteristics of UTM based on the indicators of carbon emission from the university energy consumption are divided into three; basic data, energy consumption and computed findings. This study found that the UTM's activities resulted in approximately 46,000 million tons of carbon dioxide $\left(\mathrm{MtCO}_{2}\right)$ emissions annually. A total emission of 34,119 $\mathrm{MtCO}_{2}$ was estimated from the consumption of $49,882,746 \mathrm{kWh}$ of electricity in the buildings (Table 1). In summary emission per person is given as $1.89 \mathrm{MtCO}_{2}$, and $56.5 \mathrm{KtCO}_{2}$ per unit square meter for the gross built up area. These values could be useful in setting targets for emission reduction.

Electricity Energy accounted for the largest component of UTM's carbon emission, at roughly $74 \%$. Transportation makes up the second-largest component of $\mathrm{CO}_{2}$ emission with a total of $11,872 \mathrm{MtCO}_{2}$, accounting for $26 \%$ of UTM's total annual carbon emission. UTM is largely known as a commuter campus with total commuting vehicles of about 14,540 vehicles plying the campus daily, and annual fuel consumption of 48,707 and 2,591,711 litres of diesel and petrol engine vehicles respectively (Table 2). Most of this is due to fuel consumption from staff and students commuting to school by means of private vehicles, which accounts for $75 \%$ of the transport emission (Figure 3). A relatively small proportion (approximately 14\%) of the students and staff live in residences within the campus. Majority of the commuting vehicles are private cars (77\%) and about $62 \%$ of the commuting cars are owned by faculty members and staff of the university, while $38 \%$ belong to students, visitors and private individuals operating some businesses within the campus.

The study also observed that teaching and learning activities and hostel accommodations consumed $43 \%$ and $30 \%$ of the total university electricity energy use respectively; while Central Administration and Support Services consume about $14 \%$ and the ICT consumes $13 \%$ of the total electricity supply. The teaching and learning faculties have annual carbon dioxide emission of $14,448 \mathrm{MtCO}_{2}$ and 10,197 $\mathrm{MtCO}_{2}$ for the residential hostels (Table 3). The two sectors have a combined emission of $73 \%$, or about three quarters (3/4) of the total emission 
Table 1. Basic characteristics of UTM energy consumption.

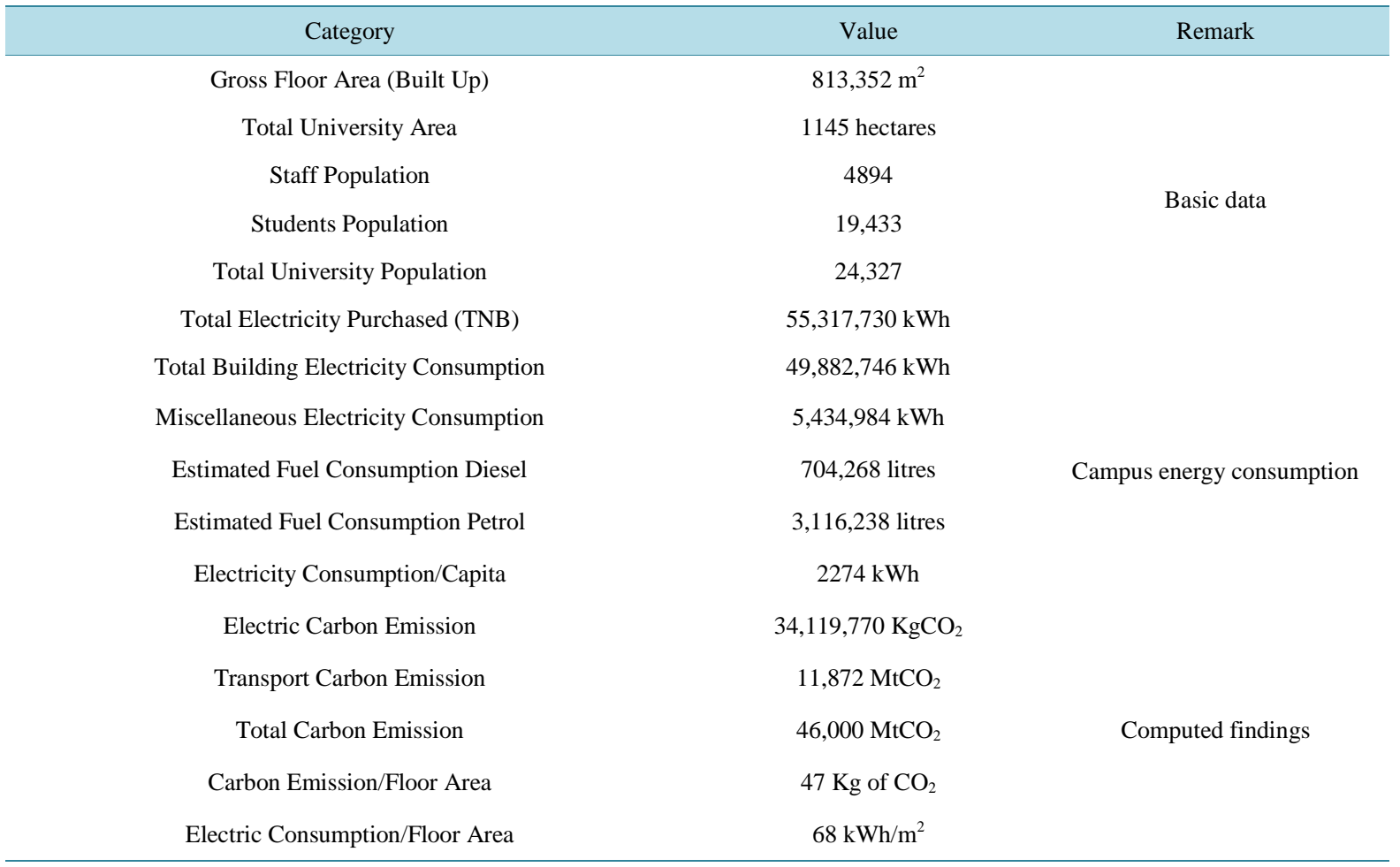

Table 2. Annual fuel consumption and carbon emission of commuting vehicles.

\begin{tabular}{|c|c|c|c|c|c|c|}
\hline \multirow{2}{*}{ Vehicle type } & \multirow{2}{*}{ Total vehicle per day } & \multicolumn{2}{|c|}{ Annual fuel consumption (litres) } & \multirow{2}{*}{$\begin{array}{l}\text { Emission per day } \\
\qquad\left(\mathrm{Kg} \mathrm{CO}_{2}\right)\end{array}$} & \multicolumn{2}{|c|}{ Carbon emission } \\
\hline & & Diesel & Petrol & & $\mathrm{Kg} \mathrm{CO}_{2}$ & $\%$ \\
\hline Car & 11,159 & - & $2,212,219$ & 19128 & $5,088,104$ & $63 \%$ \\
\hline Small van or mini van & 442 & - & 132,538 & 2287 & $3,048,381$ & $34 \%$ \\
\hline Medium van & 226 & - & 67,845 & 684 & 182,051 & $2 \%$ \\
\hline Lorries/heavy duty truck & 41 & 14,184 & - & 144 & 38,771 & $0.5 \%$ \\
\hline Bus & 115 & 34,523 & - & 350 & 93,212 & $1 \%$ \\
\hline Motorcycle & 2557 & - & 179,109 & 1548 & 411,951 & $5 \%$ \\
\hline Total & 14,540 & $\begin{array}{l}48,707 \\
\text { litres }\end{array}$ & $\begin{array}{c}\text { 2,591,711 } \\
\text { litres }\end{array}$ & $\begin{array}{c}24,141 \\
\left(24 \mathrm{MtCO}_{2}\right)\end{array}$ & \multicolumn{2}{|c|}{$\begin{array}{c}8,862,407 \\
\left(8.86 \mathrm{MtCO}_{2}\right)\end{array}$} \\
\hline
\end{tabular}

Table 3. Percentage of carbon emission by service demand sectors.

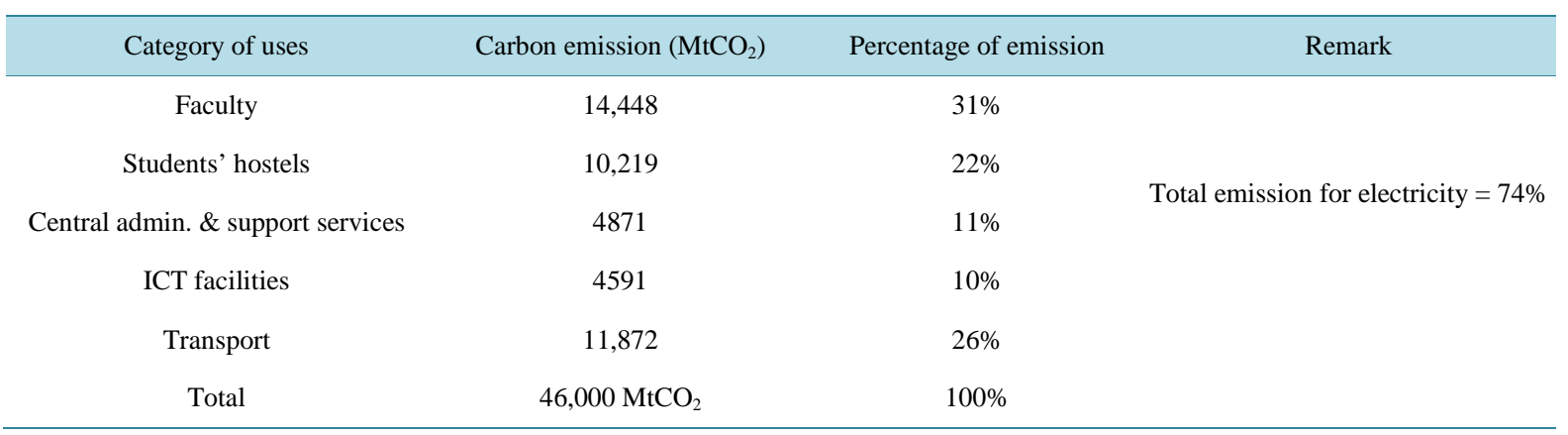




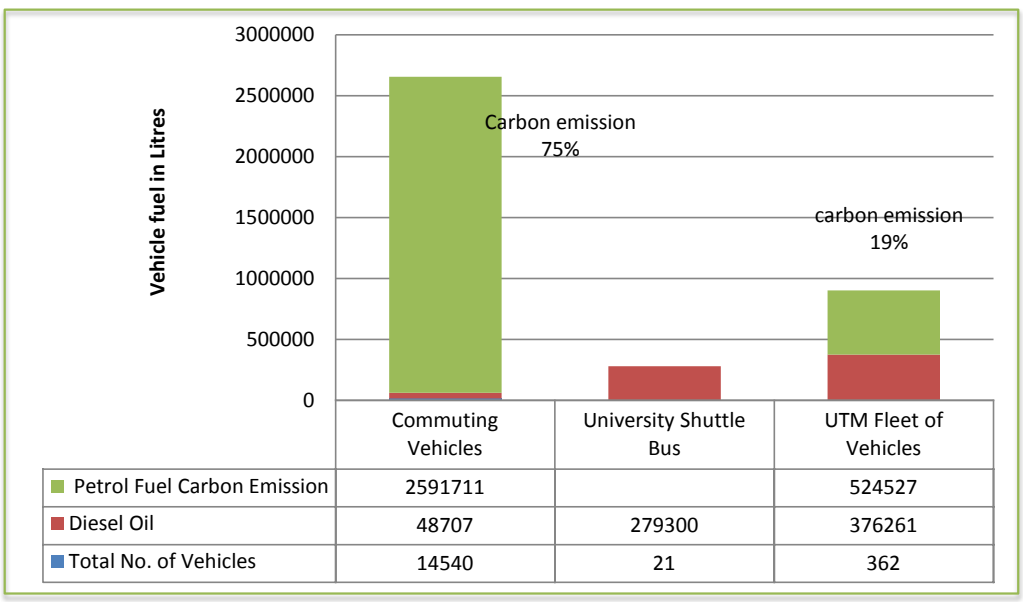

Figure 3. Summary of UTM’s carbon emission for transport sector.

of the university from electricity energy use as shown in Figure 4. Furthermore, the reason for relatively low consumption of electricity for the administrative and support activity is that the sector is operational for maximum periods of 9 - 10 hours per working day. The ICT facilities include the computer centre; the library and also the Information Technology (IT) support services for the teaching and learning as well as Central Administrative activities. It has an emission of $13 \%$ of the electricity $\mathrm{CO}_{2}$ emissions (Figure 4) and $10 \%$ of total carbon emission of the entire service sectors as presented in Table 3 . This is large in view of its physical size of $5 \%$ of the total built up area.

The high annual energy use index (AEUI) and carbon emission for ICT sector could be as a result of the electricity consumption for the population served, for instance, the library entertains about 1,083,677 visitors annually and emit about $4 \mathrm{~kg}$ of $\mathrm{CO}_{2}$ per visitors. Similarly, the computer centre (CICT) serves the entire university population, supports all university activities and is continuously operational for 24 hours of 7 days, hence, the high emission intensity.

The carbon dioxide emission of electric energy use based on demand for the cooling, lighting and other electrical appliances is as given in Figure 5. The total carbon emission for all the categories of electricity energy consumption is about $34,036 \mathrm{MtCO}_{2}$. The total electricity demand for cooling or air-conditioning is 24,711 MWh (Megawatt hour) with $\mathrm{CO}_{2}$ emission of $16,907 \mathrm{MtCO}_{2}$ and about $50 \%$ of the total emission from the university electric energy consumption. The emission for lighting purpose is about $16 \%$ while equipment and other appliances is $34 \%$ of the total. This figure compare favorably with the national averages as shown in Figure 5, and indicates strong similarity between UTM and National emission for these categories of uses.

The percentages of emissions from service demand sectors are presented in Figure 6. The Teaching and Learning Faculty tops the list with $31 \%$, followed by the transport sector with $26 \%$ of total campus emission. The students hostel accommodation has about $22 \%$ of the emission, while central administration and support services has $11 \%$ and the ICT sectors emits $10 \%$ of the total electricity emission.

Carbon emission is proportional to energy demand, therefore, the emission from service demand sectors offer the opportunity to plan the reduction of carbon emission based on service demand sectors. By this, it will be possible to view percentage emission and determine the high energy demand sectors/high emission sectors on campus which can be targeted by carbon reduction strategies towards realizing low carbon emission.

The knowledge of the sources and extent of carbon emission will facilitate the reduction of the university's contribution to global warming as a means of promoting sustainability and will enable administrators and university leaders to understand, quantify, and manage the emissions as well as make informed decisions towards reducing the global warming impact of the campus through $\mathrm{CO}_{2}$ emissions reduction.

\section{Conclusions}

Planning energy sustainability should be a continuous process that can be practiced through the adoption of a goal, research analysis, planning and effectuation of policies. Achieving low carbon and sustainable university campus requires the enshrinement of policy in the form of statements, strategies and plans to direct the physical 


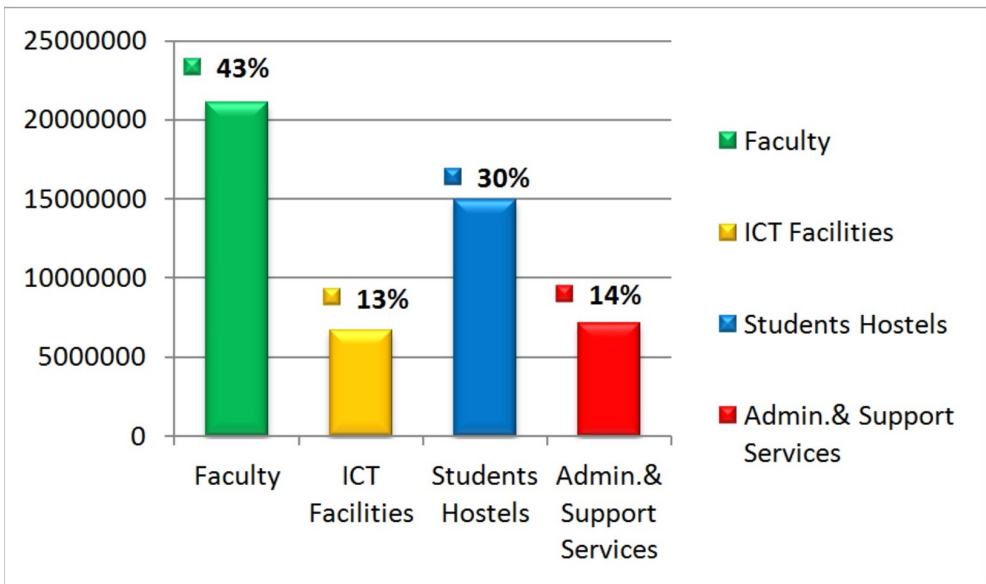

Figure 4. Carbon emission of service activities based on electricity consumption. Source: field survey 2011.

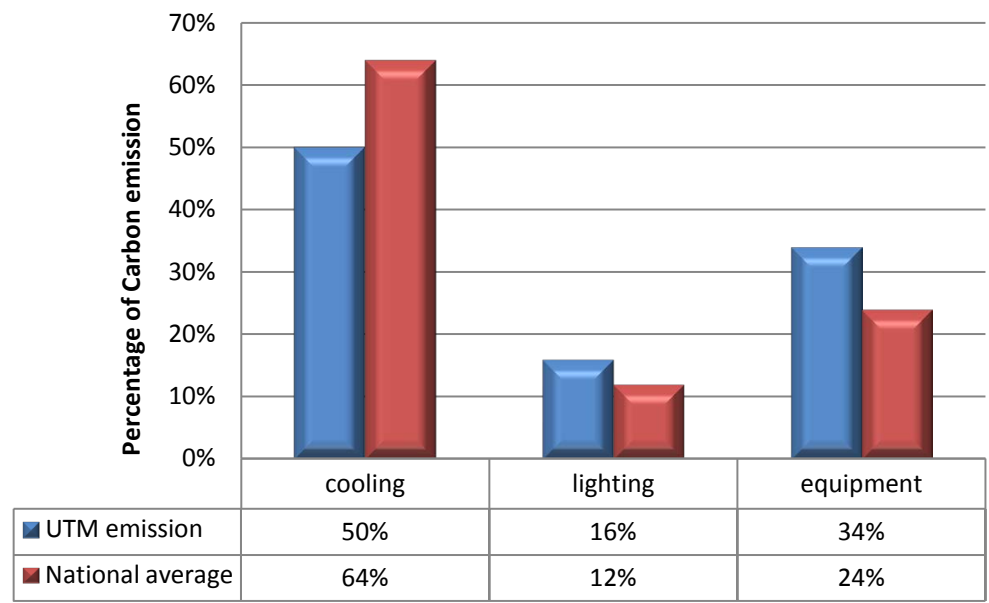

Figure 5. Carbon emission by category of uses. Source: modified after Aun 2004.

$31 \%$

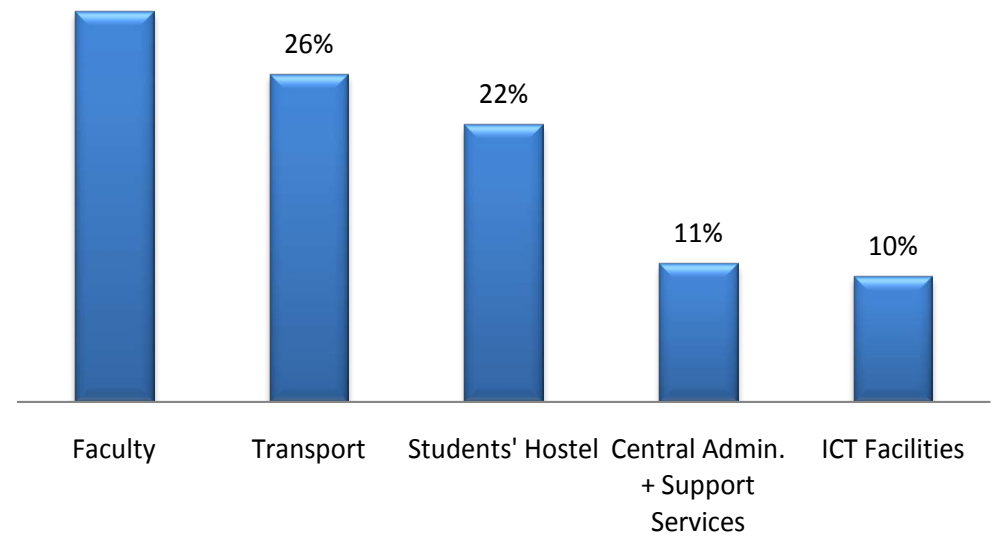

Figure 6. Percentage of annual overall university carbon emission in UTM.

operations of the university through education, research and practices that can be evaluated by a control system that would ensure optimization of energy use. However, the measures put in place to ensure implementation are 
equally important and capable of facilitating change in many institutions. Intensifying efforts to reduce the universities' contribution of greenhouse gases (GHG) through inventory of carbon emission and an assessment tool that is easier to use as well as the search for alternative energy sources would enhance the achievement of energy sustainability.

The ability to measure the extent and levels of energy use in the campus will facilitate uniformity of sustainability approach where common factors among universities are observed, i.e., energy use. Therefore, for the purpose of achieving more sustainable environment, it is desirable to practice sustainability through effective measurement of $\mathrm{CO}_{2}$ emission from energy consumption. Sustainability could be more popular among universities, by creating a consensus approach and encouraging collaboration and partnership among universities as well as the establishment of effective implementation and monitoring process of energy sustainability among the university campuses. This could limit global warming and reduce threat to global environment as well as enable the sharing of experience among the university campuses.

However, it is necessary to determine the existing levels of emission in order to apply suitable strategies and mitigation measures. For instance, strategies to stop the use of the stuff that creates greenhouse gases as much as possible as well as other measures of behavioral change such as turning off lights when not in use as well as using the fan instead of an air conditioner on a warm day could save energy in campuses and assist to achieve energy sustainability. Similarly, commitment towards exploring alternative, environmentally friendly forms of energy generation and reduced reliance on imported energy generation and also encouraging on-campus environmentally-friendly electric energy generation can enhance carbon emission reductions.

Furthermore, emission from electricity could be reduced by using more electricity efficient facilities and changing consumption behavior, while the on-campus transport emission could be improved with the adoption of policies for better on-campus transportation facilities and options. Similarly, encouraging the use of more environmentally-friendly forms of transportation as well as the use of Cleaner-burning, renewable fuels, such as biodiesel and encouraging cycling will also achieve low carbon emission in the campus.

Reducing the aggregate emission of universities worldwide is a pathway to achieving the objective of Greenpeace International of holding temperature rise to below 2 degrees Celsius [36]. Therefore, completing an assessment of energy use to determine university's contribution to global warming and conducting surveys of energy consumption within the campus is ideal for the achievement of energy sustainability. Also working with administrators and staff to implement recommendations for low carbon emission is critical to realizing low carbon emission and making improvements in university campus.

Finally, providing an energy impact assessment for the administration and developing carbon saving action plans that cut across energy, transport, buildings, housing, waste, and other issues in the university campus will ensure that rapid development occurs in an environmentally responsible and sensitive manner. However, clear responsibilities for actions of universities to set targets to reduce global $\mathrm{CO}_{2}$ emissions to below 4Gt/a in 2050 could be achieved through outlined strategies developed to assist reduction of $\mathrm{MtCO}_{2}$ in the priority areas of the university campuses.

\section{References}

[1] Abdalla, K. (2007) Energy Indicators for Sustainable Development: Country Studies on Brazil, Cuba, Lithuania, Mexico, Russian Federation, Slovakia and Thailand, United Nations Department of Economic and Social Affairs.

[2] Park, K., et al. (2003) Quantitative Assessment of Environmental Impacts on Life Cycle of Highways. Journal of Construction Engineering and Management, 129, 25-31. www.ascelibrary.org http://dx.doi.org/10.1061/(ASCE)0733-9364(2003)129:1(25)

[3] Alshuwaikhat, H.M. and Abubakar, I. (2008) An Integrated Approach to Achieving Campus Sustainability: Assessment of the Current Campus Environmental Management Practices. Journal of Cleaner Production, 16, 1777-1785. http://dx.doi.org/10.1016/j.jclepro.2007.12.002

[4] Lukman, R. (2009) Towards Greening a University Campus: The Case of the University of Maribor, Slovenia. Resources, Conservation and Recycling, 53, 639-644. http://dx.doi.org/10.1016/j.resconrec.2009.04.014

[5] Rappaport, A. (2008) Campus Greening: Behind the Headlines. Environment: Science and Policy for Sustainable Development, 50, 6-17. http://dx.doi.org/10.3200/ENVT.50.1.6-17

[6] Graedel, T.E. (2002) Quantitative Sustainability in a College or University Setting. International Journal of Sustainability in Higher Education, 3, 346-358. http://dx.doi.org/10.1108/14676370210442382

[7] Bosshard, A. (2000) A Methodology and Terminology of Sustainability Assessment and Its Perspectives for Rural 
Planning. Agriculture, Ecosystems and Environment, 77, 29-41. http://dx.doi.org/10.1016/S0167-8809(99)00090-0

[8] Jiusto, J.S. (2003) Spatial Indeterminacy and Power Sector Carbon Emissions Accounting. Ph.D. Thesis, Faculty of Clark University, Worcester.

[9] Pope, J., Annandale, D. and Morrison-Saunders, A. (2004) Conceptualising Sustainability Assessment. Environmental Impact Assessment Review, 24, 595-616. http://dx.doi.org/10.1016/j.eiar.2004.03.001

[10] Hardy, D. (2008) Cities That Don’t Cost the Earth Published by Jon Land for TCPA in Housing and Also in Communities, Local Government.

[11] Arrow, K.J. (2007) Global Climate Change: A Challenge to Policy. The Berkeley Electronic Press, Berkeley. www.bepress.com/ev

[12] Abdul-Azeez, I.A. (2012) The Development and Application of Malaysian University Carbon Emission Tool (MUCET) towards Creating Sustainable Campus. Ph.D. Thesis, UTM, Johor.

[13] Eagan, D.J., et al. (2008) Higher Education in a Warming World. The Business Case for Climate Leadership on Campus National Wildlife Federation's Campus Ecology. www.nwf.org/CampusEcology/BusinessCase

[14] Lourdel, N., Gondran, N., Laforest, V. and Brodhag, C. (2005) Introduction of Sustainable Development in Engineer's Curricula Problematic and Evaluation Methods. International Journal of Sustainability in Higher Education, 6, 254264.

[15] Balsas, C.J.L. (2003) Sustainable Transportation Planning on College Campuses. Transport Policy, 10, 35-49. http://dx.doi.org/10.1016/S0967-070X(02)00028-8

[16] Toor, W. and Havlick, S. (2004) Transportation and Sustainable Campus Communities: Issues, Examples, Solutions. Island Press, Washington DC.

[17] Dorsey, B. (2005) Mass Transit Trends and the Role of Unlimited Access in Transportation Demand Management. Journal of Transport Geography, 13, 235-246. http://dx.doi.org/10.1016/j.jtrangeo.2004.07.004

[18] Mason, I.G., Brooking, A.K., Oberender, A., Harford, J.M. and Horsley, P.G. (2003) Implementation of a Zero Waste Program at a University Campus. Resources, Conservation and Recycling, 38, 257-269. http://dx.doi.org/10.1016/S0921-3449(02)00147-7

[19] Wong, N.H. and Jusuf, S.K. (2008) GIS-Based Greenery Evaluation on Campus Master Plan. Landscape and Urban Planning, 84, 166-182. http://dx.doi.org/10.1016/j.landurbplan.2007.07.005

[20] Nilsson, J., Bjuggren, C. and Frostell, B. (1998) Greening of a Campus Restaurant at Stockholm University: Sustainable Development Audits by Means of the SDR Methodology. Journal of Environmental Management, 52, 307-315.

[21] Arendt, R. (2004) Linked Landscapes Creating Greenway Corridors through Conservation Subdivision Design Strategies in the Northeastern and Central United States. Landscape and Urban Planning, 68, 241-269. http://dx.doi.org/10.1016/S0169-2046(03)00157-9

[22] Riddell, W., Bhatia, K.K., Parisi, M., Foote, J. and Imperatore, J. (2009) Assessing Carbon Dioxide Emissions from Energy Use at a University. International Journal of Sustainability in Higher Education, 10, 266-278. http://dx.doi.org/10.1108/14676370910972576

[23] International Atomic Energy Agency (IAEA) (2007) Energy Indicators for Sustainable Development: Country Studies on Brazil, Cuba, Lithuania, Mexico, Russian Federation, Slovakia and Thailand. United Nations Department of Economic and Social Affairs, New York.

[24] Spirovski, D., Abazi, A., Iljazi, I., Ismaili, M., Cassulo, G. and Venturin, A. (2012) Realization of a Low Emission University Campus through the Implementation of Climate Action Plan. Procedia-Social and Behavioral Sciences, 4, 4695-4702. http://dx.doi.org/10.1016/j.sbspro.2012.06.321

[25] Beatty, B., et al. (2002) Building Environmental Sustainability at Bowling Green State University (Executive Summary). http://www.bgsu.edu/departments/envh/ES-summary.pdf

[26] Isham, J.T., et al. (2003) Carbon Neutrality at Middlebury College: A Compilation of Potential Objectives and Strategies to Minimize Campus Climate Impact. Draft Prepared for the Carbon Reduction Initiative at Middlebury College.

[27] Stewart, C. (2005) Ecological Footprint Progress Report. University of Toronto Mississauga, Mississauga. http://geog.utm.utoronto.ca/ecofootprint/doc/efprogressreport2005.pdf

[28] Elderkin, R. (2007) A First Step toward a Climate Neutral Pomona College: Greenhouse Gas Emissions Inventory and Recommendations for Mitigating Emissions. Pomona Campus Climate Challenge, 27 April 2007.

[29] McNeilly, L. (2008) UC Berkeley Campus Sustainability. University of California, Berkeley.

[30] Willson, R. and Brown, K. (2008) Carbon Neutrality at the Local Level: Achievable Goal or Fantasy? Journal of the American Planning Association, 74, 497-504. http://dx.doi.org/10.1080/01944360802380431

[31] Filippin, C. (2000) Benchmarking the Energy Efficiency and Greenhouse Gases Emission of School Buildings in Ar- 
gentina. Building and Environment, 35, 407-414. http://dx.doi.org/10.1016/S0360-1323(99)00035-9

[32] Chan Seong Aun, A. (2004) Energy Efficiency: Designing Low Energy Buildings Using Energy 10. Pertubuhan Arkitek Malaysia (PAM), CPD Seminar, 7th August 2004.

[33] Sathiendrakumar, R. (2003) Greenhouse Emission Reduction and Sustainable Development. International Journal of Social Economics, 30, 1233-1248. http://dx.doi.org/10.1108/03068290310500643

[34] United State Environmental Protection Agency (2006) Greenhouse Gas Emissions from the US Transportation Sector, 1990-2003. USEPA, Washington DC. www.epa.gov/otaq/climate.htm

[35] WED, IEA/ESD, Energy Statistics Division (ESD) of the International Energy Agency (IEA) (2011) IEA Energy Statistics. www.iea.org/statist/index.htm

[36] Greenpeace International, Implementation of All the Elements of Decision 1/CP.17, (b) Matters Related to Paragraphs 7 and 8 (ADP), 2013. 